DOI 10.31558/2519-2949.2019.4.14

УДК 321.7:316.070:004

ORCID ID: https://orcid.org/0000-0001-9799-9786

Стеблина Н. О., Донецький національний університет імені Василя Стуса

\title{
РЕПРЕЗЕНТАЦІЯ ПОЛІТИЧНОГО РЕЖИМУ УКРАЇНИ У НОВИНАХ ОНЛАЙН-ВИДАННЯ «УКРАЇНСЬКА ПРАВДА»
}

На основі новин незалежного українського онлайн-видання «Українська правда» встановлюється різниця між двома украӥнськими політичними режимами - часів Віктора Ющенка та часів Віктора Януковича. В иарині вітчизняного наукового дискурсу політичний режим крайни характеризується як перехідний або гібридний. За таких умов необхідними видаються методики, що дозволять точніше ідентифікувати подібні режими, а також - у майбутньому - прогнозувати зміну політичного режсиму за певними показниками. У цій статті пропонується вважати одним із індикаторів режиму взаємини між мас-медіа як суспільним інститутом та владою. За такого підходу, аналізуючи презентацію влади у публікачіях ЗМI, можна буде дійти висновків про тип політичного режиму в країні. Тому гіпотезою даного дослідження є наступне твердження: через формальний аналіз новин незалежного ЗМІ можна виявити та описати тендениії тяжіння режиму до більш демократичного та до більш авторитарного. Гіпотеза підтверджується через низку складових.

Зокрема, для перехідного режиму, що тяжіс до демократичного, характерна: більш різноманітна присутність героїв новин у заголовках, що виражається як у вищій частоті згадок (582 для Ющенка, 431 для Януковича), так і у більш довгому переліку унікальних позицій у загальному списку згадуваності (184 у Ющенка, 127 у Януковича). Наявність у новинах інших популярних політиків чи героїв новин, окрім президента та їх незначне відставання від нього за згадуваністю (у випадку Ющенка ми бачимо переважсання президента над другою позиџією (Тимоченко) на 15 пунктів, у випадку із Януковичем друга позичія (теж Тимоченко) відстає від нього на 59 пунктів). Також для новин за часів Ющенка характерна більша кількість посилань на джерела інформації в межах однієї публікаџії. С також відмінність $і$ за типами джерел: у Януковича на друге-третє місче за популярністю виходять власна інформація / власні кореспонденти та ЗМІ. Це якраз свідчить про намагання ЗМІ шукати закриту інформаиію та повідомляти про тиск на ЗМI - припускаємо, що це притаманне перехідному режиму, що тяжіє до авторитаризму та авторитарним режимам.

Ключові слова: політичний режим, перехідний політичний режим, політична журналістика, рейтинг згадуваності, джерела інформації.

Журналістику вважають «дзеркалом» для суспільства та його інститутів. Особливо важливим видається і відображення журналістикою влади - для того, аби суспільство могло контролювати іiі, робити обгрунтований вибір під час голосування та ін. Подібне сприйняття журналістики та їі ролі у суспільстві дає змогу вивчати не тільки те, наскільки добре вона виконує свої функції, та взаємодію між журналістикою та владою. Тим не менш, подібне сприйняття журналістики як «дзеркала», в якому відображується поточний стан речей, дає змогу для проведення низки досліджень, що стосуються репрезентації у журналістських матеріалах політичного режиму країни.

Подібна постановка питання дає змогу поглянути на політичний режим зі сторони, особливо, якщо йдеться про так звані «перехідні» режими, що знаходяться на межі демократичного та авторитарного. Оцінюючи взаємодію між ЗМІ та владою у подібних країнах міжнародна організація IREX зазначає, що у них “ситуація великою мірою залежить від чинного уряду та політичних сил”, відтак зміна уряду може призвести до кардинальної зміни режиму [18]. Особливо важливим тут видається виявлення у матеріалах 3МІ таких індикаторів, як свідчитимуть про ймовірність подібної зміни у майбутньому.

У цьому дослідженні застосовується саме такий підхід до публікацій у ЗМІ. На основі новин незалежного українського онлайн-видання «Українська правда» встановлюється різниця між двома

(C) Стеблина Н. О., 2019 
українськими політичними режимами - часів Віктора Ющенка та часів Віктора Януковича. Як відомо, за Ющенка Україну було визнано вільною країною, за Януковича оцінки країни погіршилися - і вона перейшла до низки частково вільних країн (див. звіти Freedom House). Відтак, припускаємо, що через формальний аналіз новин видання можна виявити та описати тенденції тяжіння режиму до більш демократичного та до більш авторитарного. Перевірка цієї гіпотези і $€$ метою цього дослідження.

Політичний режим як поняття та способи визначення політичних режимів

В. Яремчук вважає, що «фаховий розгляд функціонування політичного режиму» є важливим, особливо, якщо йдеться про країну, що знаходиться у «трансформаційному періоді» [15, с. 88]. При цьому точно визначити, яким є політичний режим у перехідних суспільствах, не завжди можливо, тож дослідження саме таких режимів дає змогу уточнити їхні ознаки [8], у нашому випадку - через репрезентацію офіційного дискурсу у ЗМІ. Подібні дослідження можуть надати додаткові аргументи для відокремлення авторитарних та демократичних режимів, оскільки останнім часом можемо говорити про профанацію поняття «політика» [2, с. 43] та тенденцію дискредитації демократії як ідеї, під час якої авторитарні та тоталітарні режими «намагаються через пересмикування фактів, фальсифікації висновків, псевдонаукові дослідження» виявити «в класичних демократичних режимах тоталітарні і авторитарні риси» [4, с. 352]. Тому, на думку Р. Буравченка, необхідні чіткіші дефініції як традиційних режимів, так і перехідних [4, с. 352].

Саме поняття політичного режиму трактується досить широко. При цьому є фахівці, що спираються тільки на закріплені у законах механізми здійснення влади, а $\epsilon$ ті, що звертають увагу на взаємини суспільства і влади, оскільки закріплене в законах (приміром, свобода слова чи вільні від тиску держави вибори) може не актуалізовуватися у реальному житті, що характерно, приміром для авторитарних та тоталітарних держав [4, с. 352] (Див. також [11, с. 282].

I. Пантелейчук зазначає, що етимологічно «режим» походить від французької «управління», додаючи, що саме поняття «політичний режим» передбачає встановлені взаємини між центральними органами держави, а також система методів і способів здійснення влади. Останню він поділяє на політичну та державну $[11$, с. 282]. У зв'язку із цим Д. Моісеєнко зазначає про існування деякої плутанини щодо дефініції «політичний режим» (можливі варіанти «державний», «політикодержавний» чи «державно-політичний») і пропонує поділяти це поняття на дві складові: соціально політичний («здійснення влади самими широкими соціальними силами (як державними, так i позадержавними)») та державно-політичний («здійснення політичної влади державними органами державної влади») [9, с. 232].

Визначення політичного режиму саме як державно-політичного дають А. Циганков: «політичний режим - сукупність владних структур, які в значній мірі контролюють або задають способи функціонування і відтворення політичного співтовариства» (цит. за [4, с. 353] та О. Свтушенко: «Порядок соціального життя, установлений державною владою» [5, с. 13]. На думку А. Трач політичний режим визначає норми політичних взаємин та «баланс сил елітних груп» [13, с. 155]. Зокрема, за словами дослідниці можна розрізняти поліцентричний політичний режим із наявністю альтернативних груп та моноцентричний - із відсутністю [13, с. 154-155]. Деякі дослідники окрім власне управління, що здійснюється владою, та взаємин між іï органами, наголошують на:

- доступі до влади, характеристиках політичних суб'єктів та способах боротьби за владу (О’Доннелл і Ф. Шміттер, цит за [11, с. 282];

- «політичному кліматі, що існує у суспільстві» [12, с. 7], відтак, зрозуміти політичний режим можна не тільки виходячи з аналізу способу управління та взаємин між органами влади, але й через суспільні настрої;

- «комплексі елементів інституціонального, соціологічного та ідеологічного порядків, що утворюють політичну владу конкретної країни на певний період (політологічний енциклоп. словник, цит за $[5$, с. 13$]$;

- співвідношенні влади та суспільства, рівні розвитку суспільно-політичних традицій, свідомості та ін. [5, с. 12];

- «процедурах і способах формування владних інститутів, стилі ухвалення політичних рішень, взаємозв'язку між владою і громадянами» [8, с. 18-19].

Відтак, усі зазначені показники можуть бути описані та вивчені для того, аби визначити тип політичного режиму. Тим не менш, одним із його індикаторів можуть бути не тільки взаємини між владою та суспільством (наявність певного клімату, форм упливу суспільства на владу), а й вужче - 
взаємини між мас-медіа як суспільним інститутом та владою. I цьому присвячена ціла низка досліджень, зокрема класичних теорій преси (див. [6], [14], [6] та ін.). Тому цілком можемо припустити, що аналіз мас-медійного контенту цілком може надати певні показники для визначення типу політичного режиму.

Тим не менш, у вітчизняних статтях, присвячених дослідженню політичного режиму України, подібним чином проблема не ставиться, хоча й побіжно зауважується залежність політичної комунікації від політичного режиму. Наприклад, I. Пантелейчук, зауважує, що у випадку імітації демократичного режиму «реальна публічна політика починає підмінятися маніпуляціями суспільною свідомістію» [11, с. 284]. Тобто збільшення маніпуляцій у мас-медіа або - ширше у публічному просторі може свідчити про тяжіння влади до авторитаризму. Схоже спостереження знаходимо у Р. Балабана, який український політичний режим характеризує як «фасадну й риторичну демократію» [1, с. 267]. «Риторичність» також можна виміряти, зокрема через невідповідність форми повідомлення та його реальному змісту або ж через ті самі маніпуляції. Цей же дослідник пропонує у цьому плані звертати увагу на цінності, які можуть визначати політичний режим [1, с. 258]. Перехідний режим України I. Мацишина характеризує через особливий дискурс, який той виробляє, зазначаючи, що дискурс влади не консолідував суспільство, а роз'єднував його: «протилежний, а в деяких випадках внутрішньо-конфліктний інституційний дискурс, був наслідком фомування однією із сторін виробників дискурсу й набував ознак асиметричності» [7, с. 55]. Ще одна заувага від С. Орлова, що пов' язує політичний режим із «легітимністю політичних інститутів», а саму легітимність із «розумінням значною частиною населення їхньої [політичних інститутів] необхідності й інформованості про їхню діяльність, що неможливо без наявності каналів безпосередньої взаємодії між інститутами та широкими верствами населення» [10, с. 123]. Підсумовуючи, можемо зазначити, що політичний режим обов'язково «промовляється» або ж проявляється у політичній комунікації - і вужче у політичних текстах ЗМІ.

Вважається, що влада за будь-якого режиму (демократичного чи авторитарного/тоталітарного) впливає на ЗМІ, тим не менш, ЗМІ мають бути незалежними від будь-якого впливу, тим більше впливу влади (і це прописано у професійних стандартах багатьох мас-медіа, див. наприклад [16]. Проте, як би там не було, не мусимо забувати про одну важливу річ, яка певним чином цю незалежність обмежує і навіть посилює у цифрові часи. Це залежність ЗМІ від влади як від джерела інформації. У цьому плані показовою є індексна теорія У. Л. Беннета. Описуючи ситуацію у США, він зазначає, що в цілому ЗМІ транслюють точку зору влади (тобто офіційний дискурс), альтернативні ж позиції можуть виникати тільки тоді, якщо є незгода між політичними елітами. Тобто альтернативні позиції виробляють не ЗМІ, як це прописано у стандартах, а саме політичні еліти, оскільки саме вони $\epsilon$ впливовими та впізнаваними для аудиторій [17]. А отже, аналізуючи репрезентацію влади у публікаціях 3МI, можна буде дійти висновків про тип політичного режиму в країні.

\section{Політичний режим в Україні}

Щодо характеристик вітчизняного режиму в цілому спостерігаємо консенсус між дослідниками. У ньому віднаходять як риси демократичного, так і авторитарного. При цьому відзначається як тенденція до повільної демократизації, так і повернення до авторитаризму.

Приміром, у 2010 році Ф. Рудич зазначав, що Україна знаходиться на роздоріжжі між тоталітарним, авторитарним та демократичним режимами (стаття була написана у 2010 р.). 3 його точки зору, поступове становлення останнього було найбільш вірогідним. Тим не менш, не виключалися і перші два варіанти [12, с. 17]. Д. Моісеєнко пише про «безперервну трансформацію» політичного режиму країни говорячи про рух від «повільної ліберизації тоталітарного режиму» через «стихійну демократизацію» до «олігархічного авторитаризму» [9, с. 231]. Сучасний його стан дослідник характеризує як «змішаний», в якому наявні як риси авторитаризму, так і демократії [9]. Так само вважає і Р. Балабан, відзначаючи, що «в Україні наявні рівновеликі вектори діаметрально протилежних настроїв»: авторитарних та демократичних [1, с. 256]. Українську демократію О. Буз називає «неконсолідованою», «нестійкою», «де старий режим зруйновано, а новий ще не можна вважати стабільним чи навіть цілком сформованим інституціонально» [3, с. 205]. На думку Г. Шипунова, Україна $\epsilon$ країною «демократичного транзиту» з явною кризою ідентичності» (цит за. [10, с. 121]), при цьому повернення до авторитарної або тоталітарної політичних систем за умови «деінституціоналізації суспільства» $є$ можливим [10, с. 119-120]. Змішаним або гібридним політичний режим сучасної України називає І. Пантелейчук, зазначаючи, що таку думку поділяє більшість дослідників. Під «гібридністю», знову ж таки, розуміється «симбіоз авторитарних і демократичних тенденцій $[11$, с. 283] або «поєднання залишків старої радянської системи та нових 
економічних і політичних інститутів» [4, с. 354]. Таким політичний режим в Україні залишається і до сьогодні (див [5]).

Оскільки українська політика орієнтується більше на президента, ніж на парламент (це підтверджується зокрема i більшою явкою на президентські вибори, ніж на парламентські), то цілком можна поставити у залежність збільшення або зменшення відсотка авторитарності / демократичності у політичному режимі України із фігурою президента. При цьому на перехідному етапі, коли нова влада змінює стару, спостерігається «низка проблем, пов’язаних із трансформацією та заміною старих еліт новими, намагання перших втримати позиції та неоднакова спроможність відтіснити їх із цих позицій» [3, с. 202]. Неоднакову спроможність якраз і можна пояснити більшою або меншою зорієнтованістю політичного лідера на авторитаризм та демократизм, що має проявлятися і у зміні норм, стилю політичної комунікації.

До того ж, типологія політичних режимів може бути вкрай розмаїтою, оскільки за заувагою Р. Буравченка, «кожен політичний є унікальним» [4, с. 354]. Тим не менш, дослідження «комунікативних проявів» режиму дозволить у подальшому укласти більш чітку типологію режимів різних типів, у тому числі й перехідних. Що, звісно, не виключатиме унікальності кожного з них.

\section{Матеріал та метод}

Матеріалом дослідження стали публікації одного 3 найстаріших мережевих видань країни сайту «Українська правда». Згідно із дослідженнями професійних громадських організаційІнституту масової інформації та «Детектор Медіа», видання вважається незалежним та демонструє високий рівень дотримання професійних стандартів. Для аналізу ми брали перші сто днів правління Ющенка (22 січня - 3 травня 2005) та Януковича (25 лютого - 5 червня 2010). Цей період ми обрали саме тому, що першим ста дням нового президента приділяється значна увага, до того ж, саме у цей час нова влада артикулює свої наміри, заперечуючи або підтримуючи рішення попередньої влади. Відтак, саме у цей час можна зрозуміти, яким буде розподіл сил у межах політичної еліти, хто домінуватиме в офіційному дискурсі і хто саме виступатиме головним джерелом інформації та ін.

3-поміж новин ми обирали ті, які журналісти видання позначали як головні новини дня. В «Українській правді»- це набір тексту заголовку прописними літерами. Подібний підхід відповідає теорії «порядку денного» (agenda setting). Згідно із нею, ЗМІ впливають на те, які теми їхні аудиторії вважають важливими [18]. Звісно, ухвалюючи свої рішення, редакції орієнтуються не тільки на власні міркування, важливими тут можуть бути чинники новинності (статус героя новини, масштабність, конфліктність та ін), у деяких випадках - уплив представників влади чи власників ЗМІ на редакції [14].

Тож, за 100 днів правління президентів із сайту було зібрано 247 текстів за 2005 рік та 256 за 2010. Аналізувалися заголовки, перші речення (або ж анонси у стрічці новин) та тексти цих новин. У заголовках було зібрано всі власні назви (прізвища та назви організацій/підприємств, географічні назви збиралися в окрему категорію). У текстах новин - усі посилання на джерела інформації.

На цьому матеріалі й перевірялася гіпотеза про те, що через формальний аналіз новин видання можна виявити та описати тенденції тяжіння режиму до більш демократичного та до більш авторитарного. Зокрема, за нашим припущенням для перехідного режиму, що тяжіє до демократичного це має підтвердитися через:

- більшу кількість згаданих у заголовках власних назв (відтак- більш різноманітна присутність героїв новин), що виражається як у вищій частості згадок, так і у більш довгому переліку унікальних позицій у загальному списку згадуваності;

- незначне переважання згадок про чинного президента, наявність уновинах інших популярних політиків чи героїв новин;

- більшу кількість згаданих у заголовках географічних назв, що має вказувати на прагнення більш демократичного режиму до співпраці із міжнародною спільнотою;

- більшу кількість посилань на джерела інформації в межах однієї публікації (дотримання стандарту «балансу думок», коли до новини включається не одна позиція, а декілька);

- більш різноманітну кількість джерел, з яких береться інформація.

Результати: рейтинг згадуваності у політичних новинах часів Ющенка та Януковича

Аналізуючи отриманий рейтинг згадуваності за часів Януковича та Ющенка (див. рис. 1), бачимо, що у 2005 році у заголовках новин було вжито 582 власні назви, у 2010 - на 151 позицію менше. Так само, менш різноманітним $є$ й перелік окремих позицій у Януковича. 


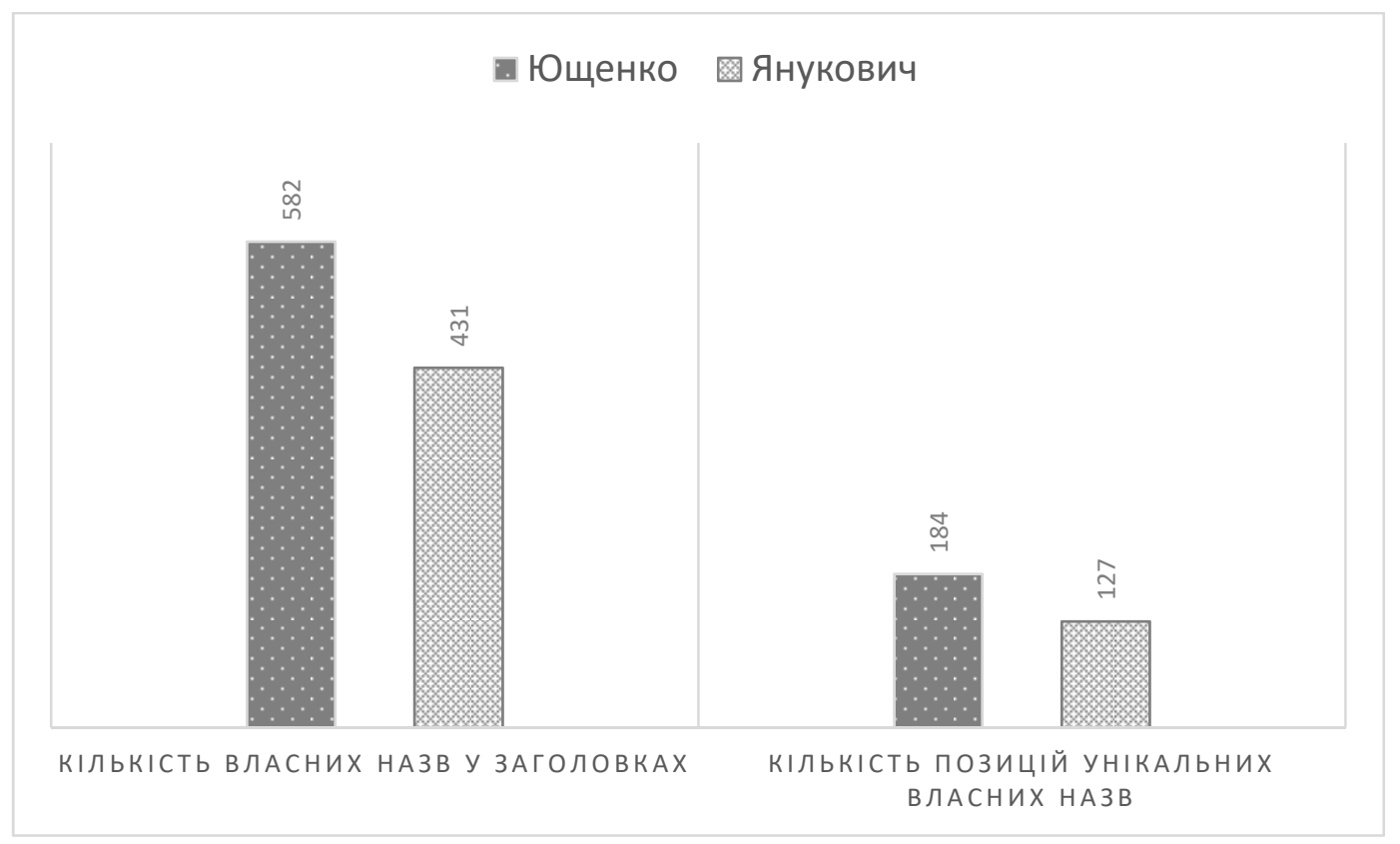

Рис. 1. Власні назви у заголовках «Украӥнської правди» (100 днів Ющенка, 100 днів Януковича)

Така картина має вказувати на більш інтенсивну комунікацію та більшу залученість різноманітних політичних акторів за часів Ющенка, що в цілому є характерним для демократичного режиму.

Тепер подивимося на розподіл згадувань між президентом та іншими політиками/інститутами (у діаграму включено тих/ті, що мали 10 згадок і більше) - див. рис. 2, 3.

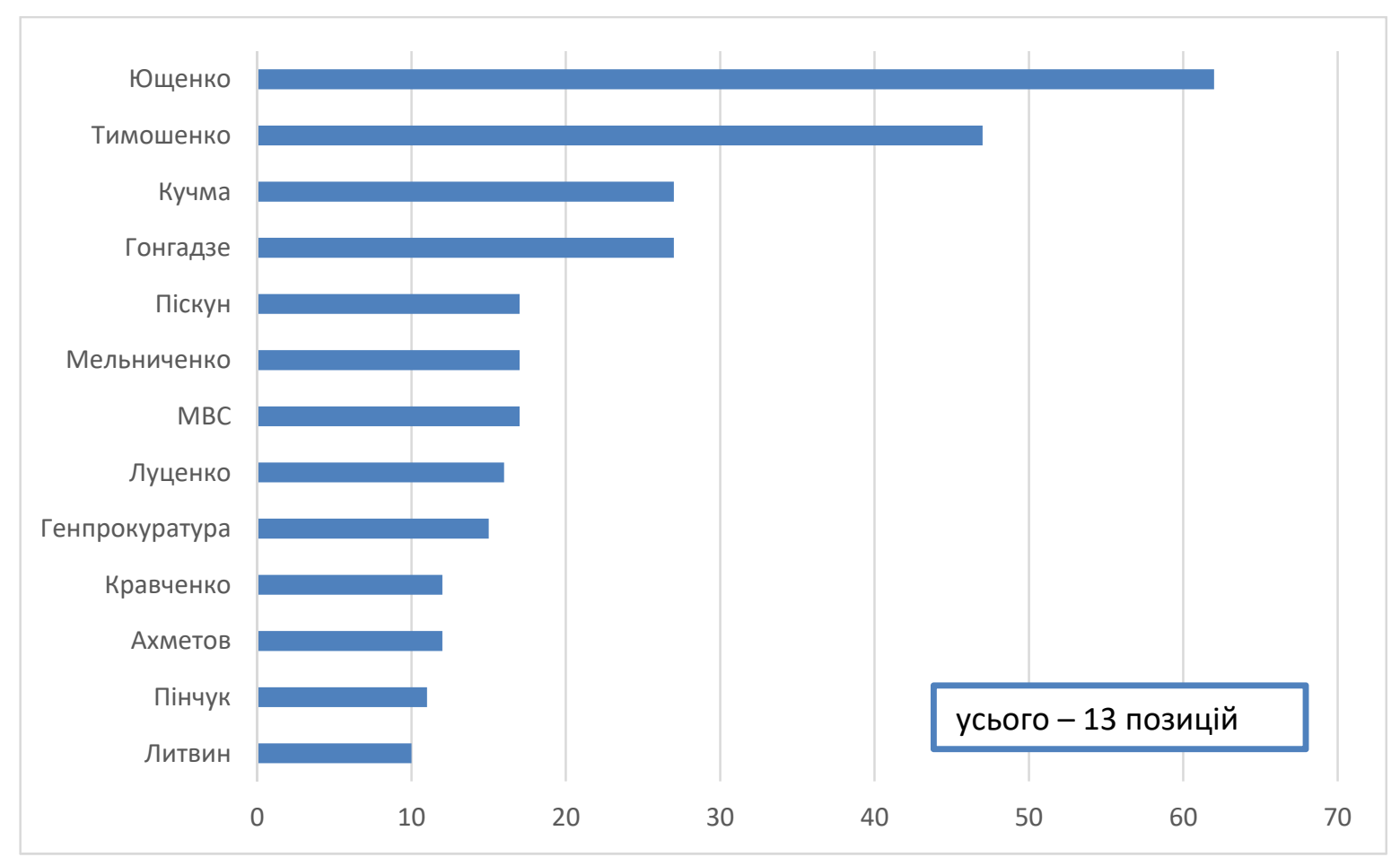

Рис. 2. Рейтинг згадуваності у заголовках «Украйнської правди» (100 днів Ющенка) 


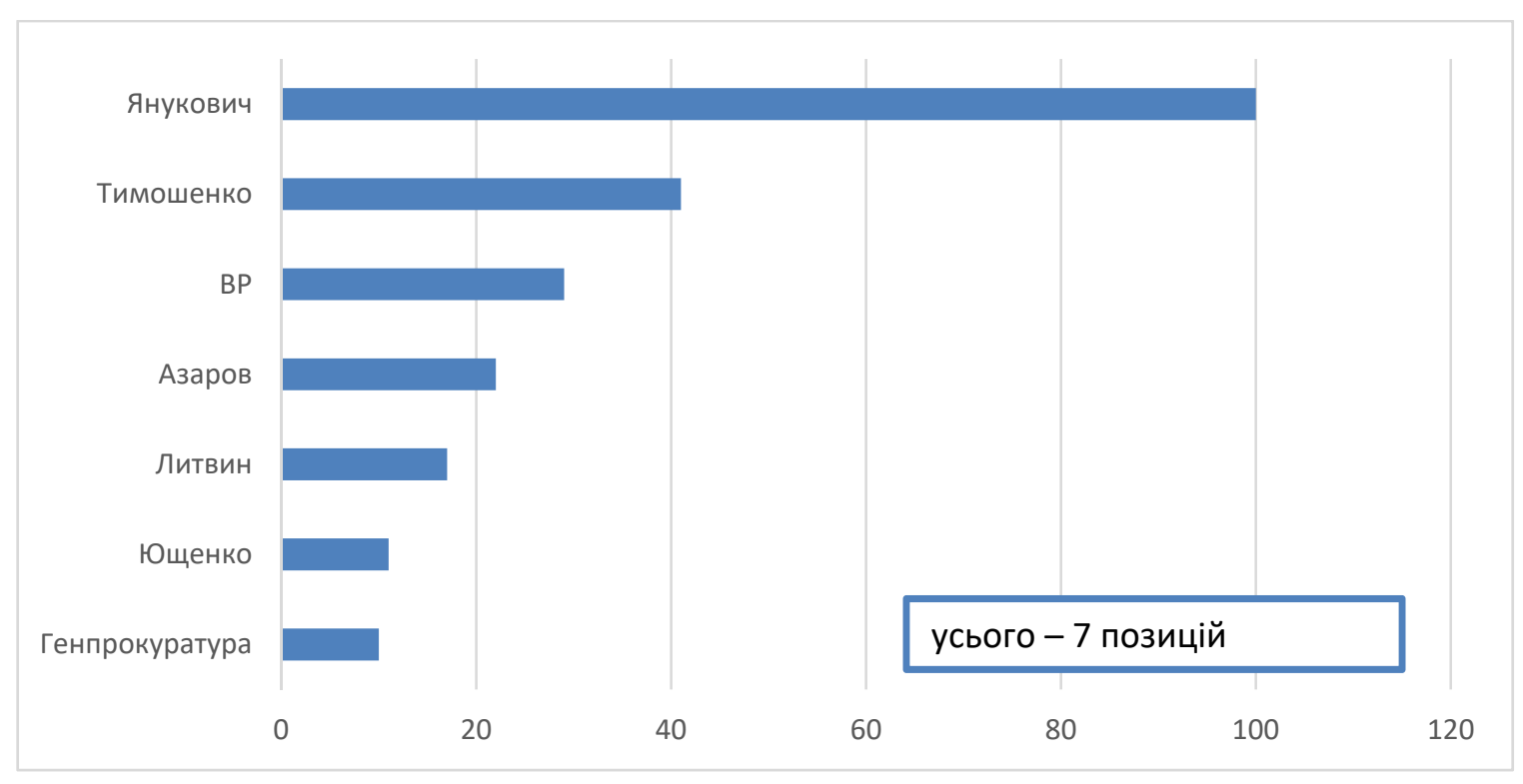

\section{Рис. 3. Рейтинг згадуваності у заголовках «Украйнськой правди»} (100 днів Януковича)

Якщо у випадку Ющенка ми бачимо переважання президента над другою позицією (Тимошенко) на 15 пунктів, що має свідчити про майже рівноцінний уплив цих двох політиків під час 100 днів третього президента - у сприйнятті ЗМІ. То у випадку із Януковичем більшість уваги зосереджено на ньому. І друга позиція (теж Тимошенко) відстає від нього на 59 пунктів.

Також цікаво, що у топ згадуваності у випадку з Ющенком потрапляють його спільники (на той час) та високопосадовці: Тимошенко, Луценко (+МBC), Піскун (+Генпрокуратура), представники великого бізнесу та персоналії, пов'язані із розслідуванням убивства Гонгадзе. У Януковича картина інша - на перший план після президента вийшла Тимошенко (спочатку у зв'язку із небажанням піти з посту прем'єра, під кінець 100 днів - у зв'язку із розслідуванням). Після неї бачимо Верховну Раду, теж через скандал із «тушками» та ухваленням так званих «Харківських угод».

\section{Географія новин}

Щодо географічних назв - маємо визнати, що подібний аналіз не є ефективним саме у плані аналізу новин, які редакція позначає як найбільш важливі. Тому що до таких текстів найчастіше уналежнюються саме внутрішні загальнонаціональні події, тобто ті, що відбуваються у межах країни у її столиці. Тим не менш, деякі відмінності можна побачити (див. табл. 1).

Кількість різних географічних назв у заголовках у Януковича та Ющенка однакова, однаковим також $є$ розподіл між згадками українських міст та зарубіжних. Тим не менш, різною $є$ кількість позицій. При цьому, у Януковича $є$ значна перевага у сторону згадок Росії. Розрив між другою позицією - у 23 пункти. У Ющенка найбільш популярною також є Росія, тим не менш, розрив 5 пунктів.

Тим не менш, для більш повної картини для вимірювання географії новин потрібно або збільшити період аналізу, або ж уналежнювати до підрахунку усі новини дня.

\section{Результати: джерела новин (кількість та типи)}

Для аналізу цього показника до уваги бралися тільки заголовки, що містили прізвище президента. Щодо джерел новин, то середня кількість джерел на одну новину у Ющенка трохи більша, ніж у Януковича: 1,44 та 1,35. Тим не менш, бачимо, що переважна більшість текстів містить усього одне джерело інформації. Це означає, що журналісти переважно не шукають альтернативних джерел для новин, в заголовках яких згадується президент. Тим не менш, цей показник $є$ типовим і для сучасної української онлайн-журналістики, де переважна більшість текстів пишеться на основі однієї точки зору, що є порушенням стандарту балансу думок (принципу надання альтернативної точки зору) та інколи точності (принципу перевірки інформації).

Коли ми розподіляємо джерела новин за типами, то, знову ж таки, бачимо суттєвий «перекіс» у сторону президентів, а також значну відмінність за категоріями «ЗМІ» та «власна інформація/власні джерела» у Януковича (див. табл. 2). 
Згадування географічних назв у заголовках новин «Української правди»

(100 днів Ющенка, 100 днів Януковича)

\begin{tabular}{|c|c|c|c|c|c|c|c|}
\hline \multicolumn{4}{|c|}{ Ющенко } & \multicolumn{4}{|c|}{ Янукович } \\
\hline \multicolumn{2}{|l|}{ Україна } & \multicolumn{2}{|l|}{ Інші країни } & \multicolumn{2}{|l|}{ Україна } & \multicolumn{2}{|l|}{ Інші країни } \\
\hline Броди & 1 & Бельгія & 1 & Івано-Франківськ & 2 & Бельгія & 1 \\
\hline Дніпро & 3 & Ватикан & 2 & Буковина & 1 & Білорусь & 1 \\
\hline Донецьк & 8 & Великобританія & 3 & Бориспіль & 1 & Європа, ЄС & 4 \\
\hline Київ & 6 & Віргінські острови & 4 & Донецьк & 3 & Польща & 2 \\
\hline Крим & 1 & Європа, ЄС & 6 & Київ & 9 & Росія & 27 \\
\hline Миколаїв & 1 & Ізраїль & 1 & Крим & 5 & \multirow[t]{8}{*}{ СРCP } & \multirow[t]{8}{*}{1} \\
\hline Одеса & 1 & країни НАТО & 1 & Львів & 3 & & \\
\hline Тернопіль & 1 & Мальдіви & 1 & Рівне & 1 & & \\
\hline Ужгород & 1 & Росія & 11 & Тернопіль & 1 & & \\
\hline Хмельницький & 2 & США & 5 & \multirow[t]{4}{*}{ Харків } & \multirow[t]{4}{*}{2} & & \\
\hline Чернігів & 1 & Туркменістан & 1 & & & & \\
\hline Закарпаття & 1 & \multirow[t]{2}{*}{ Угорщина } & \multirow[t]{2}{*}{1} & & & & \\
\hline Запоріжжя & 1 & & & & & & \\
\hline усього Україна & 28 & усього інші країни & 37 & усього Україна & 28 & усього інші країни & 36 \\
\hline \multicolumn{3}{|l|}{ усього згадок } & 65 & \multicolumn{3}{|l|}{ усього згадок } & 64 \\
\hline \multicolumn{3}{|l|}{ усього позицій } & 25 & \multicolumn{3}{|l|}{ усього позицій } & 16 \\
\hline
\end{tabular}

Табличя 2

Топ-5 джерел у публікаціях про 100 днів Ющенка, 100 днів Януковича

\begin{tabular}{|l|c|l|c|}
\hline \multicolumn{2}{|c|}{ Ющенко } & \multicolumn{2}{c|}{ Янукович } \\
\hline Ющенко & $60,3 \%$ & Янукович & $58,4 \%$ \\
\hline Тимошенко & $4,8 \%$ & влас.кор./iнф. & $18,8 \%$ \\
\hline Порошенко & $3,2 \%$ & ЗМІ & $7,9 \%$ \\
\hline Мороз & $3,1 \%$ & Герман & $5,9 \%$ \\
\hline Мельниченко & $4,7 \%$ & Тимошенко & $5,9 \%$ \\
\hline
\end{tabular}

Високе використання президентів як джерел не є чимось незвичним, бо зазвичай влада усіх рівнів $€$ найбільш розповсюдженим постачальником інформації для ЗМІ. Тим не менш, подібна ситуація все ж дає підстави для висновку про специфіку репрезентації офіційного дискурсу у ЗМІ й підтверджує індексну теорію У. Л. Беннета - про залежність мас-медіа від влади, зокрема як від джерела інформації. Проте тут ми бачимо й відмінність. За часів Януковича на друге-третє місце виходять власна інформація / власні кореспонденти та ЗМІ. Це якраз свідчить про намагання ЗМI шукати закриту інформацію та повідомляти про тиск на ЗМІ - припускаємо, що це притаманне перехідному режиму, що тяжіє до авторитаризму та авторитарним режимам. За демократичних режимів та перехідних режимів, що тяжіють до демократичних, подібні показники відсутні, оскільки влада встановлює більш відкриті взаємини із журналістами та виробляє більше інформації (зокрема, промов - Простий кількісний підрахунок промов на офіційному сайті президента України показує значне переважання кількості промов Ющенка над Януковичем). 


\section{Висновки}

Отже, в Україні як країні із перехідним режимом, залежно від фігури президента, але й від інших факторів, спостерігаються коливання як до більш демократичного, так i до більш авторитарного режимів. Перехідні режими, як i традиційні демократичні, авторитарні чи тоталітарні, є важливими для вивчення - особливо у наш час, коли існує тенденція до підміни понять або ж до їхнього розмивання (намагання представити демократичні режими авторитарними $\mathrm{i}$ навпаки). Оскільки саме поняття політичного режиму визначається через низку різноманітних показників (наявність законів, взаємодія органів влади, влади та суспільства тощо), доцільною вважається розробка методики, яка б уможливлювала ідентифікацію режиму (у тому числі й перехідного) через зіставлення системи показників. У нашому випадку це стало можливим завдяки аналізу політичної комунікації, зокрема політичних текстів у ЗМІ.

Застосований у дослідженні рейтинг згадуваності показав значну відмінність між політичним режимом часів Ющенка (із тяжінням до демократичного) та Януковича (із тяжінням до авторитарного). За 100 днів Ющенка маємо більшу кількість і різноманітність присутності героїв новин. При цьому, окрім самої фігури президента з різних причин на першому плані $\epsilon$ й інші політичні суб'єкти. Щодо Януковича - як кількість, так і різноманітність суттєво зменшується. А президент значно переважає за згадками у найважливіших новинах 3MI.

Аналіз географічних назв не показав такого ж різноманіття, оскільки у нашій вибірці найчастіше траплялися загальнонаціональні внутрішні політичні новини. Тим не менш, за часів Януковича очевидною є зосередженість на одній із країн (Росія), що значно переважає над іншими. Тобто у випадку із перехідним режимом, що тяжіє до авторитарного, маємо меншу різноманітність $і$ за параметром географії новин (щоправда, це спостереження потребує подальших уточнень на ширшому матеріалі).

Використання джерел новин підтверджує припущення про більшу кількість джерел інформації (а отже, збалансованість новин) за часів режиму, що тяжіє до демократичного, хоча в обидвох випадках (як за Януковича, так і за Ющенка) відсоток посилань на першу особу держави був однаково високим. Тим не менш, було знайдено відмінність у використанні джерел за типами. За Януковича журналісти більше зверталися до власних кореспондентів та джерел для того, аби отримати закриту інформацію або ж представити альтернативні версії подій.

Отримані результати дозволяють стверджувати, що застосування подібної методики для ідентифікації політичних режимів може виправдати себе не тільки у випадку визначення перехідних, але й традиційних демократичних чи авторитарних / тоталітарних режимів.

\section{Бібліографічний список:}

1. Балабан Р. Політичний режим в Україні в аспекті суспільних цінностей. Наукові записки Інституту політичних і етнонаціональних досліджень ім. І. Ф. Кураса, 2012. № 6. С. 253-268.

2. Білий О. Легітимація і сучасний політичний режим. Наукові записки Інституту політичних $i$ етноначіональних досліджень ім. І. Ф. Кураса, 2013. № 1. С. 43-54.

3. Буз, О. Політичний режим України в перехідний період. Історико-політичні проблеми сучасного світу, 2011. № 23-24. С. 201-206.

4. Буравченко Р. В. Політичний режим сучасної України: перспективи еволюції. Гілея: науковий вісник, 2016. № 109. С. 352-356.

5. Свтушенко О. Політичний режим та його роль у регулюванні взаємовідносин суспільства й держави. Наукові праці Чорноморського державного університету імені Петра Могили комплексу "Києво-Могилянська академія". Серія : Політологія, 2016. № 284(272). С. 12-16.

6. Іванов, В. Ф. Основні теорії масової комунікації і журналістики: Навчальний посібник. Київ: Центр вільної преси. 2010. - 258 с.

6. Лалл, Д. Мас-медіа, комунікація, культура: глобальний підхід. Київ: К. І. С., 2002. - 264 с.

7. Мацишина І. В. Формування політичної реальності Украӥни. Київ: ТОВ «Твори», 2019. - 376 с.

8. Мацієвський Ю. Між авторитаризмом і демократією: політичний режим після "помаранчевої революції". Політичний менеджмент, 2006. № 5. С. 18-32.

9. Моісеєнко Д. Політичний режим постсоціалістичної України як елемент форми перехідної держави. Публічне право, 2016. № 4. С. 231-238.

10. Орлов, С. Трансформація політичної системи в сучасній Україні: проблеми інституційного аналізу. Вісник Львівського університету, 2014. № 4, С. 119-134.

11. Пантелейчук, I. В. Політичний режим в Україні: проблеми демократичного транзиту. Актуальні проблеми державного управління, 2010. № 2. С. 282-289.

12. Рудич, Ф. М. Політичний режим та народовладдя: методологічний контекст. Наукові записки Інституту політичних і етноначіональних досліджень ім. І. Ф. Кураса НАН Украӥни, 2010. № 1. С. 7-26. 
13. Трач, А. С. Політичний режим пострадянської України: між поліцентризмом та моноцентризмом. Актуальні проблеми політики, 2015. № 55. С. 154-162.

14. Штромайєр, Г. Політика і мас-медіа. Київ: Києво-Могилянська акад, 2008. - 303 с.

15. Яремчук, В. Д. Міський політичний режим у Львові: внутрішні і зовнішні чинники формування та еволюції. Наукові записки Інституту політичних і етнонаціональних досліджень ім. І. Ф. Кураса НАН Украӥни, 2016. № 1. С. 88-109.

16. BBC. The BBC's Editorial Values and Standards. URL https://www.bbc.com/editorialguidelines (дата звернення: 10.11.2010)

17. Bennett W. L., Lawrence R. G., Livingston S. When the Press Fails, Political Power and the News Media from Iraq to Katrina. Chicago: Chicago Press, 2007.

18. Irex. Media Sustainability Index. URL https://www.irex.org/resource/media-sustainability-index-msi (дата звернення: 10.11.2010)

18. McCombs, M., Valenzuela, S. The Agenda-Setting Theory. CUADERNOS DE INFORMACIÓN, 2007. № 20, C. 44-50.

\section{References:}

1. Balaban R. Politychnyy rezhym v Ukrayini v aspekti suspil'nykh tsinnostey. Naukovi zapysky Instytutu politychnykh i etnonatsional'nykh doslidzhen' im. I. F. Kurasa, 2012. \# 6. P. 253-268.

2. Bilyy O. Lehitymatsiya i suchasnyy politychnyy rezhym. Naukovi zapysky Instytutu politychnykh $i$ etnonatsional'nykh doslidzhen' im. I. F. Kurasa, 2013. \# 1. P. 43-54.

3. Buz, O. Politychnyy rezhym Ukrayiny v perekhidnyy period. Istoryko-politychni problemy suchasnoho svitu, 2011. \# 23-24. P. 201-206.

4. Buravchenko R. V. Politychnyy rezhym suchasnoyi Ukrayiny: perspektyvy evolyutsiyi. Hileya: naukovyy visnyk, 2016. \# 109. P. 352-356.

5. Yevtushenko O. Politychnyy rezhym ta yoho rol' u rehulyuvanni vzayemovidnosyn suspil'stva y derzhavy. Naukovi pratsi Chornomors 'koho derzhavnoho universytetu imeni Petra Mohyly kompleksu "Kyyevo-Mohylyans'ka akademiya". Seriya : Politolohiya, 2016. \# 284(272). P. 12-16.

6. Ivanov, V. F. Osnovni teoriyi masovoyi komunikatsiyi i zhurnalistyky: Navchal'nyy posibnyk. Kyiv: Tsentr vil'noyi presy. 2010. $-258 \mathrm{p}$.

6. Lall, D. Mas-media, komunikatsiya, kul'tura: hlobal'nyy pidkhid. Kyiv: K. I. S., 2002. - 264 p.

7. Matsyshyna I. V. Formuvannya politychnoyi real'nosti Ukrayiny. Kyiv: TOV «Tvory», 2019. - 376 c.

8. Matsiyevs'kyy Yu. Mizh avtorytaryzmom i demokratiyeyu: politychnyy rezhym pislya "pomaranchevoyi revolyutsiyi". Politychnyy menedzhment, 2006. \# 5. P. 18-32.

9. Moiseyenko D. Politychnyy rezhym post·sotsialistychnoyi Ukrayiny yak element formy perekhidnoyi derzhavy. Publichne pravo, 2016. \# 4. P. 231-238.

10. Orlov S. Transformatsiya politychnoyi systemy v suchasniy Ukrayini: problemy instytutsiynoho analizu. Visnyk L'vivs'koho universytetu, 2014. \# 4, P. 119-134.

11. Panteleychuk, I. V. Politychnyy rezhym v Ukrayini: problemy demokratychnoho tranzytu. Aktual'ni problemy derzhavnoho upravlinnya, 2010. \# 2. P. 282-289.

12. Rudych, F. M. Politychnyy rezhym ta narodovladdya: metodolohichnyy kontekst. Naukovi zapysky Instytutu politychnykh i etnonatsional'nykh doslidzhen' im. I. F. Kurasa NAN Ukrayiny, 2010. \# 1. P. 7-26.

13. Trach, A. S. Politychnyy rezhym postradyans'koyi Ukrayiny: mizh politsentryzmom ta monotsentryzmom. Aktual'ni problemy polityky, 2015. \# 55. P. 154-162.

14. Shtromayyer, H. Polityka i mas-media. Kyiv: Kyyevo-Mohylyans'ka akad, 2008. - 303 p.

15. Yaremchuk, V. D. Mis'kyy politychnyy rezhym u L'vovi: vnutrishni i zovnishni chynnyky formuvannya ta evolyutsiyi. Naukovi zapysky Instytutu politychnykh i etnonatsional'nykh doslidzhen' im. I. F. Kurasa NAN Ukrayiny, 2016. \# 1. P. 88-109.

16. BBC. The BBC's Editorial Values and Standards. URL https://www.bbc.com/editorialguidelines (дата звернення: 10.11.2010)

17. Bennett W. L., Lawrence R. G., Livingston S. When the Press Fails, Political Power and the News Media from Iraq to Katrina. Chicago: Chicago Press, 2007.

18. McCombs, M., Valenzuela, S. The Agenda-Setting Theory. CUADERNOS DE INFORMACIÓN, 2007. \# 20, C. 44-50.

\section{Steblyna N. O. Ukrainian political regime representation in news of online media «Ukrayins`ka Pravda»}

The difference between two political regimes of the times of Viktor Yuschenko and the times of Viktor Yanykovych is stated on the material of news analysis of independent online media «Ukrayins ka Pravda». In the field of Ukrainian scientific discourse the political regime of the country is being characterized as transitional one or hybrid one. Thus, some new techniques for the transitional regimes identification are needed to define them more correctly (as being predominantly authoritative or democratic). Additionally 
in the future with the techniques, it would be possible to forecast the regimes changes. In the paper the interrelations between the mass media as the social institution and the ruling government are proposed to be considered as an indicator of the regime. And within the formal analysis of news of the independent mass media it is possible to discover the tendencies of the regime's orientation towards authoritarism or democracy. That is the main hypothesis of the research. It is confirms through some components.

The transitional regime with democratic orientation may be identified through the larger presence of news heroes in headlines, which is expressed with the larger mentions frequency (582 for Yuschenko, 431 for Yanukovych) and with the longer list of unique positions in the general list of mentions (184 for Yuschenko, 127 for Yanukovych). The presence of other popular figures in the news (except the president) and their insignificant lag is also needed. For instance in Yuschenko case the second most popular persona is Tymoshenko (with 15 points lag), in Yanukovych case Tymoshenko is also the second, but with 59 points lag. For the news in the Yuschenko times the larger number of references on sources within one news item is discovered. There is also the difference with the sources types. In the times of Yanukovych the second and the third most popular position are own correspondent / own information and other mass media. It may be considered as an attempt to seek closed information and to inform about pressure on mass media. It is supposed, that such a feature exists in the regime with the orientation towards authoritarism and authoritative regime.

Key words: political regime, transitional political regime, political journalism, mentions rating, news sources 